\title{
FLAWED CURRENCY AREAS AND VIABLE CURRENCY AREAS: EXTERNAL IMBALANCES AND PUBLIC FINANCE IN THE TIME OF THE EURO
}

\section{ALDO BARBA AND GIANCARLO DE VIVO}

\section{Università di Napoli Federico II}

\begin{abstract}
The main problem discussed in this paper is whether a balance of payments constraint exists within the Euro area. It is argued that the question of a member state's foreign position is still relevant, at difference from what happens in successful currency areas like the USA, where persistent imbalances in the payments from one district to another are acceptable and are made sustainable by financial transfers revolving around the system of taxes and transfers and the public debt. A currency area is an area where the price of a deposit with the banking system is the same wherever the deposit is held (i.e. there is uniformity in the value of commercial bank money). Persistent imbalances in payments between regions within the area are to be settled in either the common currency or (which is basically the same thing) the public debt. But while this is acceptable in the USA, it is far from acceptable in the Euro area, where creditor countries (Germany being by far the most important) clamour for a settlement in 'hard assets', like, e.g. state-owned real estate, if not gold. This means that a balance of payments constraint still binds state members of the Euro area, and is a serious threat to its survival.
\end{abstract}

JEL Classification: E58; F32; F42; H71; H72

\section{INTRODUCTION}

It would appear as a now largely accepted view that the economic crisis in which Europe has been entangled for the last 4 or 5 years has shown that there are faults in the architecture of the European Monetary Union.

Disregarding the explanations according to which the root of the problems lies in the profligacy of some of the states which are part to this union, the analysis which is generally regarded as the most satisfactory (or least unsatisfactory) is that which adopts the standpoint of the literature on Optimal Currency Areas. So far as this literature does not conceive the establishment of an optimal currency area as the 'natural' result of market forces-in particular, of complete freedom of capital movements - it can envisage fiscal policy as something which, rather than being a 
cause of disruption, may have a role to play - through its redistributive and stabilizing functions-in overcoming the structural problems of a currency area. Many authors who move in this perspective share the view that at the core of the problems within the Euro area there is a lack of fiscal capacity at the federal level. However, as soon as an explanation is given of how this lack of fiscal capacity would affect the (mal)functioning of the area, and in particular, how it should be remedied, one finds that the view which has come to prevail is that distributive neutrality and a balanced budget must be warranted. ${ }^{1} \mathrm{~A}$ federal fiscal policy is invoked not in order to ensure adequate levels of aggregate demand in the longer term, but simply to provide a 'fiscal insurance'-, i.e., an insurance cover against unanticipated countryspecific shocks, which the private financial market would not be able to provide, as a consequence of imperfections to its functioning. This approach reflects the idea (i) that no question of aggregate demand exists in the longer term; therefore, the level of production has a trend which is 'natural', affected only by the 'fundamental forces of productivity and thrift', and the problem is simply that of not allowing temporary deviations from it (permanent shocks being only susceptible to be managed through wage and price deflation and labour force migration); (ii) that the need for a federal fiscal policy is linked to the asymmetric nature of temporary shocks across countries, so that support for the negative production gap in some countries would be offered by the positive production gap in others, through a purely redistributive fiscal policy; a federal fiscal policy ought to be essentially distributionally neutral in the longer term, as nobody would accept to be permanently deprived of part of what he produces in exchange for nothing.

The optimal currency area theory is in essence the study of the conditions to be satisfied for the regions composing it to have a balance of (current) payments equilibrium in the medium/long term: in fact a currency area is regarded as optimal not because there is no external equilibrium condition between its regions to be satisfied, but because it would tend towards an equilibrium in which each of the single regions would reach an even balance of current payments. This literature regards the experience of individual nation states as evidence of an optimal currency area. It is noticeable instead that a single state or a true federation of states - the optimal currency area par excellence - often shows the opposite feature: a persistent external disequilibrium between its single regions. A currency area is viable if it allows persistent imbalances to take place in the current account of the regions of which it is composed. In other words, a viable currency area is an area within which there is no binding balance of payments constraint. For example, between states of the USA, there is no doubt that some are persistently net importers from the rest of the country. ${ }^{2}$ The same is

${ }^{2}$ It is to be noticed that, while there is a wealth of statistics on US inter-state commodity flows, statistics on the inter-state current accounts are hardly available, and completely absent from the US politico-economic debate. 
true within the single European countries. ${ }^{3}$ A second point to emphasize is that in the decades preceding the economic and monetary union, fiscal policy within individual European countries was not limited to the contrast of temporary shocks. It was aimed at ensuring adequate levels of aggregate demand, regardless of the uncertain distinction between temporary and permanent deviations of production from its alleged natural (long-term) growth rate.

The two issues of the external constraint and persistent budget deficits are closely linked. Nation states are in fact viable currency areas not because they simply oppose temporary and asymmetric shocks, but because- not having within themselves a balance of payments constraint - they could pursue expansionary fiscal policies without worrying about keeping a balanced current account between all sub-areas composing them. From this point of view, the central issue is to understand why what works within individual or federal nation states does not work in the set of European countries that have introduced a common currency.

We may notice here that there has been a considerable shift in the opinion on whether the external constraint exists or not as among the member countries of the Euro area. In a rather triumphant report of the European Commission on the occasion of the 10th anniversary of the Euro it was unreservedly asserted that in the Euro area 'current account constraints and exchange risk premiums have disappeared' (EU, 2008, p. 152). Behind this complacent view, there was not so much the idea that the external constraint within the union had been eliminated, but rather that the abolition of exchange rates and complete freedom of capital movements were sufficient to ensure that the current account of each member state would have tended to balance. After the global financial crisis hit the Euro zone, many had second thoughts, and started to maintain that the European common currency is not by itself sufficient to make the notion [of a Member State's foreign position] irrelevant' (Giavazzi \& Spaventa, 2010, p. 10). There would seem to be at present a consensus on this position. Yet, it seems to us that no clear explanation has been provided of why and through which mechanisms the question of a member state's foreign position is still relevant, at difference from what happens in successful currency areas as for example the USA.

The present paper addresses this issue with a particular emphasis on the role of federal fiscal policies in the Euro area. Our line of reasoning is that, even within a single country, growth is never a territorially homogeneous process, and persistent differences in growth rates between different areas of the country tend to create persistent imbalances. If we look at examples of currency areas which have lasted for a long time without breaking up, these persistent real imbalances are accepted by surplus regions and are made sustainable by financial transfers revolving around the system of taxes and transfers and the public debt. According to those who believe

${ }^{3}$ A particularly interesting (and intriguing) case in point is that of unified Germany, which, after an initial stage when it seemed that a catching-up process had been triggered, is now exhibiting the classical scenario of a dual system in which backward Eastern regions are net importers from the rest of the country. This situation does not appear to be a threat to the monetary unity of the country. 
that market forces can correct imbalances of a real kind (i.e. through wage and price deflation, or through factor mobility), it is preferable to leave the real imbalances unmanaged, since this would automatically lead to their elimination. From our standpoint, these stabilizing market forces do not exist, and the fact that the financial management is successful is viewed positively, since imbalances would otherwise become unsustainable, leading to the fragmentation of the area. A federal fiscal policy in the European Union should play a much larger role than that of offering insurance against asymmetric fiscal shocks or that of ensuring a stabilizing fund from which to draw financial resources in emergency situations.

The paper is divided into five sections. In Section 2, we present the main data on differences in per capita GDP and personal income between the states of the European Union and of the USA; then a comparison is offered of the differences between the various states of the Euro area and between their regions. Section 3 compares federal and local tax and transfer systems in Europe and in the USA. Section 4 discusses the question of the settlement of external imbalances. Section 5 explains how imbalances in the payments of the countries of the Euro area are financed by the European Central Bank through the TARGET system, and makes a comparison between it and the ISA system - the US counterpart to the TARGET system. Section 6 draws the main implications of our argument regarding the goals of public finance in the EU.

\section{TERRITORIAL DISPARITIES, REGIONAL PUBLIC FINANCE INFLOWS AND CURRENT ACCOUNT DEFICITS}

Growth is never a territorially homogeneous process. Territorial differences in per capita output and income are substantial. This is true not only for inter-state differences, but also for inter-regional differences within the same state.

Despite relevant statistical problems, ${ }^{4}$ some facts and trends concerning USA and Europe's territorial disparities are well defined. The most important facts appear to be the following:

(i) Although personal income inequality is larger in the USA than in Europe and manufacturing is more geografically concentrated in the USA than in Europe, inter-state inequality in per capita gross domestic product in the European Union is twice that in the USA. This result changes when considering the

${ }^{4}$ A comparison of per capita regional output is not a simple task to perform. First, results are strongly dependent on the size of the area chosen as a reference point (in the present paper, we will refer to the EU's NUTS2 regional breakdown). Moreover, a meaningful comparison should be made in real terms (by deflating RGDP). When these comparisons cover longer periods of time and/or regions that have different price dynamics and currencies, price deflators are not consistent in both the time and space dimensions: all the pitfalls of using Purchasing Power Parities cannot be avoided, and they are made worse by the comparison of years distant from each other. Finally, the various measures of regional income inequality may give different results. On the effects of using PPP data, see Gasic \& Kurkowiak (2012). On the various measures of regional income inequality, see Shankar \& Shah (2003, pp. 1422-25). 
group of European states that are part of the Euro area. This group of states has a dispersion in the average levels of per capita product similar to that of the states that make up the USA.

(ii) During the period of time from World War II until the end of the 1970s, differences in per capita output across US states ${ }^{5}$ and across European states narrowed substantially: the high growth period saw a reduction in inter-state inequalities. Since the end of the 1970s, the trend towards greater income equality has been reversed.

(iii) The halt in the trend towards inter-state income equality is clearly recorded in the USA, while in Europe it is partially obscured by the entry of new countries into the community. Some of these new entrants have actually recorded higher growth rates than core countries, therefore closing the gap between the set of EU27 states. In any case, it remains true that also in Europe, since the beginning of the 1980s, there is an increase in inter-state disparities if we consider only the core countries of the monetary union.

(iv) In Europe, there is no decrease in intra-state regional inequality (whether new entrants are excluded or not). The years when European states reached an exceptionally high level of economic and financial integration did not favour any recovery of the less developed regions of the countries that make up the European project. ${ }^{6}$ Intra-state inequality has been more pronounced in the new entrants that have approached the levels of the average per capita output of the core countries, and less marked (in some cases it has actually decreased), in the core European countries, which instead saw their product stagnate.

(v) Per capita Regional Primary Income (RPI) - the income of private households cashed in a given region regardless of its source-is less unequally distributed than per capita Regional Gross Domestic Product (RGDP). Per capita Regional Disposable Income (RDI) - which is obtained when monetary transfers less taxes on income and wealth are added to the RPI-is less unequally distributed than per capita RPI. The state action, therefore, plays an important role in levelling regional inequalities. In Europe, this levelling is strong but remains confined within each state; in the USA it is less relevant, but it occurs both within states and between states (more on this in Section 3).

(vi) In Europe, regions within a single state record persistent imbalances in their external trade, while the external trade for the state as a whole tends to be balanced. Over the last decade, some new EU entrants showed imbalances in the external trade also at the national level. In the USA, there are regional imbalances in the external trade both within each state and between different states.

5 On US state per capita income long-run trend, see Coughlin \& Mandelbaum (1988).

${ }^{6}$ On the worsening of intra-state income inequality in the EMU see Bouvet (2010). See also Martin (2001). 
Figure 1a shows the dispersion of average state per capita GDP in the European countries and in the USA over the last decade. ${ }^{7}$ In all US states per capita GDP, weighted on the basis of the state population, differed from the national value by an average of $10 \%$ in 1997 , and by an average of $14 \%$ in 2011 . In the Euro area, there is a decrease from $10 \%$ in 1997 to $7.9 \%$ in 2002, and it is then trendless until 2009, when it starts to increase, reaching back $10 \%$ in 2011 . The dispersion in the EU27 area instead fell from $26 \%$ in 1997 to $17 \%$ in 2009 (a reduction which is due to the strong growth of some new entrants), and then halted. ${ }^{8}$

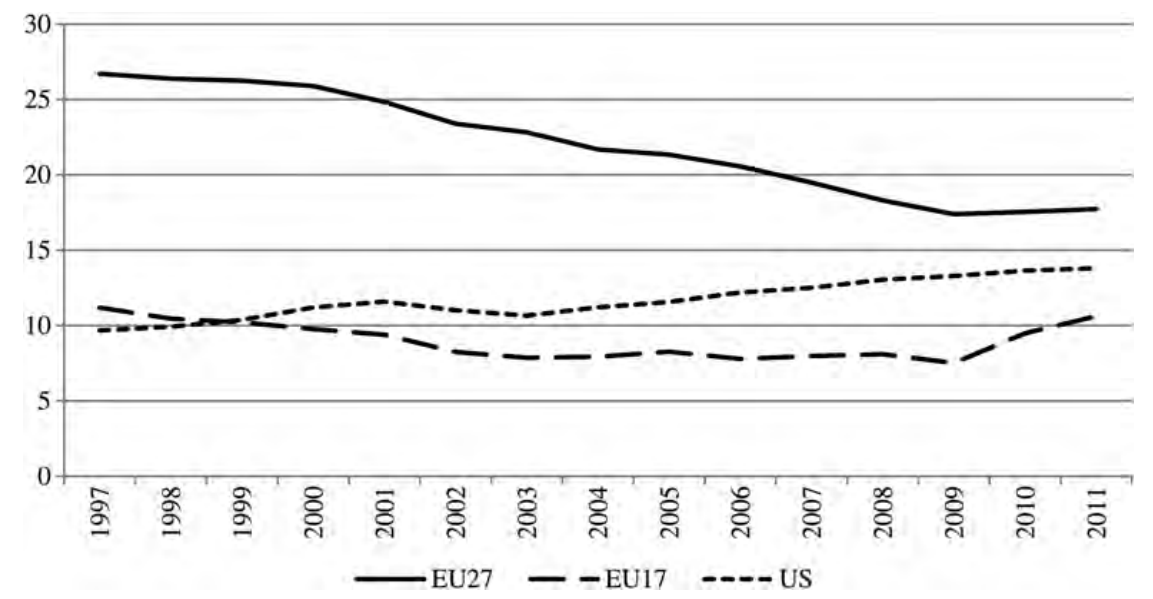

FIGURE 1A. Dispersion in per capita GDP between states in Europe and in the USA (PPP $€$ and chained 2005 US\$) (Source: BEA and EUROSTAT).

Figure $1 \mathrm{~b}$ repeats the same calculation shown in Figure 1a for the three main countries of the Euro area (Germany, France and Italy), starting with 1960. In the three decades from 1960 to 1990, the dispersion of per capita GDP between these three countries (which represent more than $60 \%$ of the population and of the product of the whole Euro area) halved (from 18 to 9\%). In 1991, a further reduction was entirely due to German unification, and the consequent lowering of German per capita GDP towards that of France and Italy. Since the early 1990s, the convergence process has stopped, and over the last decade there has actually been

${ }^{7}$ For a given territory (a single state or a federation of states) the dispersion index is given by the sum of the absolute differences between average GDP (or income) per inhabitant in each sub-area of that territory (y) and whole territory's GDP (or income) per inhabitant (Y), weighted on the basis of the sub-area share of population $(\mathrm{p} / \mathrm{P})$, and expressed in percent of the territorial GDP (or income) per inhabitant: $D=100 \frac{1}{Y} \sum_{i=1}^{n}\left|\left(y_{i}-Y\right)\right|\left(\frac{p_{i}}{P}\right)$. For a detailed analysis of the convergence process among the regions of EU27, see Eurostat (2012, pp. 18-30).

${ }^{8}$ Using non-PPP data a similar trend for the European countries can be detected, although in correspondence of higher levels of dispersion. 
an inversion, mainly due to slower growth of per capita output in Italy (the difference between Germany and France not having substantially risen).

After dealing with dispersion between US states and between EU states, we can turn to dispersion within each EU17 state. The details of each EU17 state are

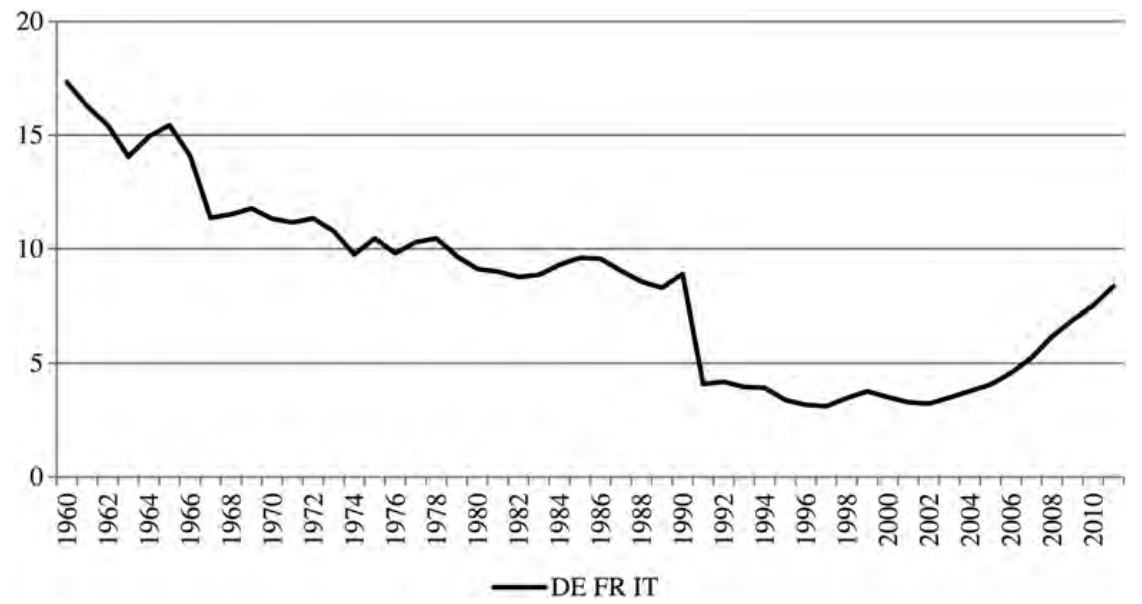

FIGURE 1в. Dispersion in per capita GDP between Germany, France and Italy (2005 market prices) (source: AMECO).

recorded in Table 1 for the year 2009. While between the 17 Euro countries dispersion is $7.5 \%$, within these countries it is $23 \%$ for France, $22.3 \%$ for Italy and $16.1 \%$ for Germany - a dispersion generated by the centre-periphery divide in France, the North-South divide in Italy and the West-East divide in Germany. ${ }^{9}$ In any case, it remains true that within the Euro countries the spread in RGDP is much higher than inter-member state dispersion: in Austria, which has the lowest level of intra-state dispersion (15\%), this is twice the level of inter-state dispersion. Narrowing the focus to the main core countries, this still holds, though attenuated by the reversion of the long run trend in inter-state disparity recorded since the inception of the Maastricht Treaty.

In Tables 2 and 3, the dispersion indexes for the same set of regions are given for both per capita regional income and per capita regional disposable income. The passage from per capita RGDP to per capita primary income shows a reduction in the dispersion, mainly due to the fact that incomes generated in metropolitan areas spread to adjacent regions. ${ }^{10}$ However, the most productive regions tend to coincide with those that host wealthier individuals, except for very small states in which the difference between the regions in which wealth is produced and that in which it is cashed

9 Germany's dispersion is largely mitigated by the different price levels in the two parts of the country. On the other hand, France's territorial dispersion is of a different nature than that of the other countries: excluding Île de France, the dispersion index (c. 10\%) is the lowest among the EU17 countries. 
TABLE 1.

Per capita GDP and RGDP in the Euro area NUTS2 regions in 2009 (1000 PPP €)

\begin{tabular}{|c|c|c|c|c|c|c|c|}
\hline Country & & Poorest region & & Richest region & & $\begin{array}{l}\text { Max/Min } \\
\text { ratio }\end{array}$ & $\begin{array}{l}\text { Dispersion } \\
\text { coefficient }\end{array}$ \\
\hline Belgium & 27.7 & Prov. Hainaut & 18.1 & $\begin{array}{l}\text { Région de } \\
\text { Bruxelles }\end{array}$ & 52.5 & 2.9 & 24.2 \\
\hline Germany & 27.2 & $\begin{array}{l}\text { Brandenburg - } \\
\text { Nordost }\end{array}$ & 18.4 & Hamburg & 44.1 & 2.4 & 16.1 \\
\hline France & 25.4 & Picardie & 19.4 & Île de France & 41.5 & 2.2 & 23.1 \\
\hline Italy & 24.4 & Campania & 15.8 & Lombardia & 31.3 & 2.0 & 22.4 \\
\hline Austria & 29.3 & Burgenland & 19.8 & Wien & 37.9 & 1.9 & 15.1 \\
\hline Netherlands & 31.0 & Flevoland & 22.7 & Groningen & 40.0 & 1.8 & 17.0 \\
\hline Spain & 24.2 & Extremadura & 16.9 & $\begin{array}{l}\text { Comunidad } \\
\text { de Madrid }\end{array}$ & 31.9 & 1.9 & 18.5 \\
\hline Portugal & 18.8 & Norte & 14.9 & Lisboa & 26.4 & 1.8 & 34.3 \\
\hline Ireland & 30.0 & $\begin{array}{l}\text { Border, Mid. } \\
\text { and West. }\end{array}$ & 20.8 & $\begin{array}{l}\text { South. and } \\
\text { East. }\end{array}$ & 33.3 & 1.6 & 23.0 \\
\hline Greece & 22.1 & Ipeiros & 15.3 & Attiki & 29.1 & 1.9 & 33.0 \\
\hline Slovenia & 20.5 & $\begin{array}{l}\text { Vzhodna } \\
\text { Slovenija }\end{array}$ & 16.9 & $\begin{array}{l}\text { Zahodna } \\
\text { Slovenija }\end{array}$ & 24.6 & 1.5 & 28.5 \\
\hline Slovakia & 17.0 & $\begin{array}{l}\text { Východné } \\
\text { Slovensko }\end{array}$ & 11.5 & $\begin{array}{l}\text { Bratislavský } \\
\text { kraj }\end{array}$ & 41.8 & 3.6 & 44.7 \\
\hline Finland & 26.9 & Itä-Suomi & 20.0 & Åland & 38.5 & 1.9 & 23.1 \\
\hline Cyprus & 23.5 & - & - & - & - & - & - \\
\hline Estonia & 14.9 & - & - & - & - & - & - \\
\hline Malta & 19.3 & - & - & - & - & - & - \\
\hline Luxembourg & 62.5 & - & - & - & - & - & - \\
\hline
\end{tabular}

Source: EUROSTAT.

becomes somewhat meaningless (the Netherlands is a case in point). Of greater interest, for our line of argument, is the comparison of per capita RPI and per capita RDI. This shows a steady reduction in dispersion, clearly seen in France, Germany and Italy, even though in Italy it starts from much higher levels of spatial dispersion.

10 See for example the cases of Région de Bruxelles-Capitale and the case of Groningen both of which lose the primacy of the richest region, or the case of Île de France which, while maintaining this primacy, records a per capita net primary income equal to $\sim 60 \%$ of its per capita RGDP. 
TABLE 2.

Per capita household PI and RPI in the Euro area NUTS2 regions in 2009 (1000 PPP €)

\begin{tabular}{|c|c|c|c|c|c|c|c|}
\hline Country & & Poorest region & & Richest region & & $\begin{array}{l}\mathrm{Max} / \mathrm{min} \\
\text { ratio }\end{array}$ & $\begin{array}{l}\text { Dispersion } \\
\text { coefficient }\end{array}$ \\
\hline Belgium & 20.4 & Prov. Hainaut & 15.9 & $\begin{array}{l}\text { Prov. Vlaams- } \\
\text { Brabant }\end{array}$ & 26.0 & 1.6 & 11.6 \\
\hline Germany & 20.7 & Chemnitz & 14.2 & Hamburg & 27.2 & 1.9 & 12.6 \\
\hline France & 18.9 & $\begin{array}{l}\text { Languedoc- } \\
\text { Roussillon }\end{array}$ & 15.5 & Île de France & 26.6 & 1.7 & 14.3 \\
\hline Italy $^{a}$ & 17.5 & Calabria & 11.1 & Lombardia & 22.5 & 2.0 & 22.9 \\
\hline Austria & 20.9 & Kärnten & 19.1 & Vorarlberg & 22.5 & 1.2 & 3.4 \\
\hline Netherlands & 19.9 & Groningen & 16.5 & Utrecht & 23.0 & 1.4 & 18.3 \\
\hline Spain & 16.2 & Extremadura & 11.5 & $\begin{array}{l}\text { Comunidad } \\
\text { de Madrid }\end{array}$ & 21.5 & 1.9 & 18.9 \\
\hline Portugal & 11.7 & Norte & 9.5 & Lisboa & 16.3 & 1.7 & 39.1 \\
\hline Ireland & 15.8 & $\begin{array}{l}\text { Border, Mid. } \\
\text { and Wes. }\end{array}$ & 13.0 & $\begin{array}{l}\text { Southern and } \\
\text { Eastern }\end{array}$ & 16.9 & 1.3 & 22.3 \\
\hline Greece & 14.5 & Dytiki Ellada & 11.4 & Attiki & 17.7 & 1.6 & 29.7 \\
\hline Slovenia & 13.3 & $\begin{array}{l}\text { Vzhodna } \\
\text { Slovenija }\end{array}$ & 12.1 & $\begin{array}{l}\text { Zahodna } \\
\text { Slovenija }\end{array}$ & 14.7 & 1.2 & 24.5 \\
\hline Slovakia & 10.2 & $\begin{array}{l}\text { Východné } \\
\text { Slovensko }\end{array}$ & 7.8 & $\begin{array}{l}\text { Bratislavský } \\
\text { kraj }\end{array}$ & 19.1 & 2.5 & 39.7 \\
\hline Finland & 16.6 & Itä-Suomi & 13.2 & Åland & 20.3 & 1.5 & 24.8 \\
\hline Cyprus & 14.7 & - & - & - & - & - & - \\
\hline Estonia & 8.0 & - & - & - & - & - & - \\
\hline Malta & - & - & - & - & - & - & - \\
\hline Luxembourg & 24.1 & - & - & - & - & - & - \\
\hline
\end{tabular}

Source: EUROSTAT.

${ }^{\mathrm{a}} 2006$.

Regions which record a disposable income higher than primary income are not so common. In spite of this, the poorest regions almost always have a disposable income about equal to their primary income, while in rich regions the disposable income is consistently lower than the primary income. Put otherwise, the poor regions receive an amount of public transfers approximately equal to the amount of 
TABLE 3.

Per capita household DI and RDI in the Euro area NUTS2 regions in 2009 (1000 PPP $€$ )

\begin{tabular}{|c|c|c|c|c|c|c|c|}
\hline Country & & Poorest region & & Richest region & & $\begin{array}{l}\mathrm{Max} / \mathrm{min} \\
\text { ratio }\end{array}$ & $\begin{array}{l}\text { Dispersion } \\
\text { coefficient }\end{array}$ \\
\hline Belgium & 16.6 & Prov. Hainaut & 14.4 & $\begin{array}{l}\text { Prov. Vlaams- } \\
\text { Brabant }\end{array}$ & 19.7 & 1.4 & 8.1 \\
\hline Germany & 17.9 & $\begin{array}{l}\text { Mecklenburg- } \\
\text { Vorpom. }\end{array}$ & 14.4 & Hamburg & 22.8 & 1.6 & 8.1 \\
\hline France & 16.8 & $\begin{array}{r}\text { Nord - Pas- } \\
\text { de-Calais }\end{array}$ & 14.6 & Île de France & 20.7 & 1.4 & 7.5 \\
\hline Italy $^{a}$ & 15.5 & Campania & 10.9 & $\begin{array}{l}\text { Emilia } \\
\text { Romagna }\end{array}$ & 19.3 & 1.8 & 18.9 \\
\hline Austria & 18.4 & Kärnten & 17.6 & Niederösterreich & 20.0 & 1.1 & 3.4 \\
\hline Netherlands & 14.3 & Groningen & 11.9 & Utrecht & 16.0 & 1.3 & 19.3 \\
\hline Spain & 14.8 & Extremadura & 11.3 & País Vasco & 19.7 & 1.7 & 15.2 \\
\hline Portugal & 11.7 & Norte & 10.0 & Lisboa & 14.7 & 1.4 & 32.3 \\
\hline Ireland & 15.1 & $\begin{array}{l}\text { Border, Mid. } \\
\text { and Wes. }\end{array}$ & 13.6 & $\begin{array}{l}\text { Southern and } \\
\text { Eastern }\end{array}$ & 15.7 & 1.2 & 18.7 \\
\hline Greece & 15.1 & Ionia Nisia & 12.1 & Attiki & 18.1 & 1.5 & 27.7 \\
\hline Slovenia & 12.1 & $\begin{array}{l}\text { Vzhodna } \\
\text { Slovenija }\end{array}$ & 11.4 & $\begin{array}{l}\text { Zahodna } \\
\text { Slovenija }\end{array}$ & 13.0 & 1.1 & 23.2 \\
\hline Slovakia & 9.6 & $\begin{array}{l}\text { Východné } \\
\text { Slovensko }\end{array}$ & 8.0 & $\begin{array}{l}\text { Bratislavský } \\
\text { kraj }\end{array}$ & 15.1 & 1.9 & 34.3 \\
\hline Finland & 14.1 & Itä-Suomi & 12.7 & Åland & 16.5 & 1.3 & 21.7 \\
\hline Cyprus & 14.7 & - & - & - & - & - & - \\
\hline Estonia & 7.4 & - & - & - & - & - & - \\
\hline Malta & - & - & - & - & - & - & - \\
\hline Luxembourg & 22.9 & - & - & - & - & - & - \\
\hline
\end{tabular}

Source: EUROSTAT.

${ }^{\mathrm{a}} 2006$.

tax paid (regional government spending being thus entirely deficit financed), while in rich regions the balance between taxes and transfers records a surplus that in some cases outpaces regional public spending. For example, in Belgium's poorest region (Prov. Hainault) private households' disposable income is equal to $90 \%$ of 


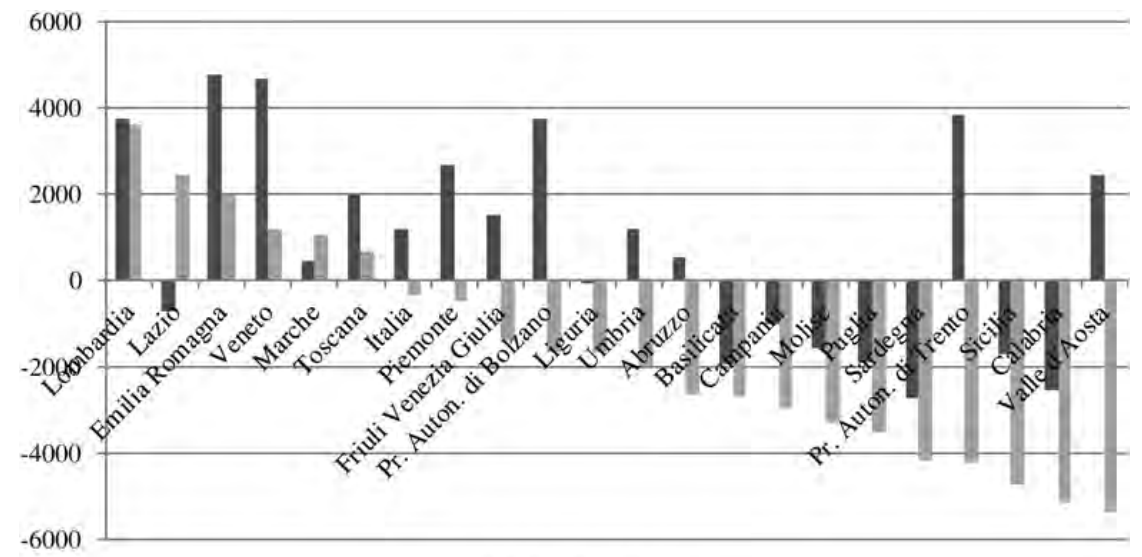

$=\mathrm{T}-\mathrm{G}-\mathrm{TR}=\mathrm{E}-\mathrm{M}$

FIGURE 2. Italy 2009. Current public finance balance and net exports by region (€ per capita) (source: ISTAT).

primary income; in the richest region (Prov. Vlaams-Brabant) it is equal to $75 \%$. In Languedoc-Roussillon (the poorest French region in terms of primary income) this ratio is $98 \%$; in Île the France, the richest region, it is $78 \%$. In Germany, Chemnitz shows a ratio of $106 \%$, Hamburg of $84 \%$. In Italy, Calabria has a ratio of $100 \%$, Lombardia records a ratio of $83 \%$. In Spain's poorest region (Extremadura) the ratio is $98 \%$; in the Comunidad de Madrid it is $83 \%$. The calculation of the fiscal residual is of course a very complicated exercise, which cannot be carried out by simply subtracting taxes from transfers. However, the way in which these net transfers move is on the whole clear: in all European countries rich regions subsidize poor regions to a greater or lesser degree, and in an amount which depends on the more or less restrictive fiscal policy stance.

These net financial transfers between regions are associated with a corresponding flow of real resources. Territorial differences in income levels as between regions do not by themselves necessarily imply corresponding external imbalances. As a matter of fact, however, richer regions tend to generate a flow of net exports towards poorer regions of the same state. This can be seen as the counterpart of the system of tax and expenditure showing a positive balance (taxes $>$ expenditure) for richer regions, and a negative balance (taxes < expenditure) for poorer regions. It is in fact the system of taxes and expenditure which allows an imbalance between exports and imports to go on without an indefinitely rising indebtedness of the poorer towards the richer regions. Figure 2 shows the net flow of exports (per capita) for each Italian region in 2009 (regions are ordered starting from the highest net flow). Figure 2 also shows the difference between per capita current revenues and current public expenditure for each Italian region. The richest region (Lombardia) records a 

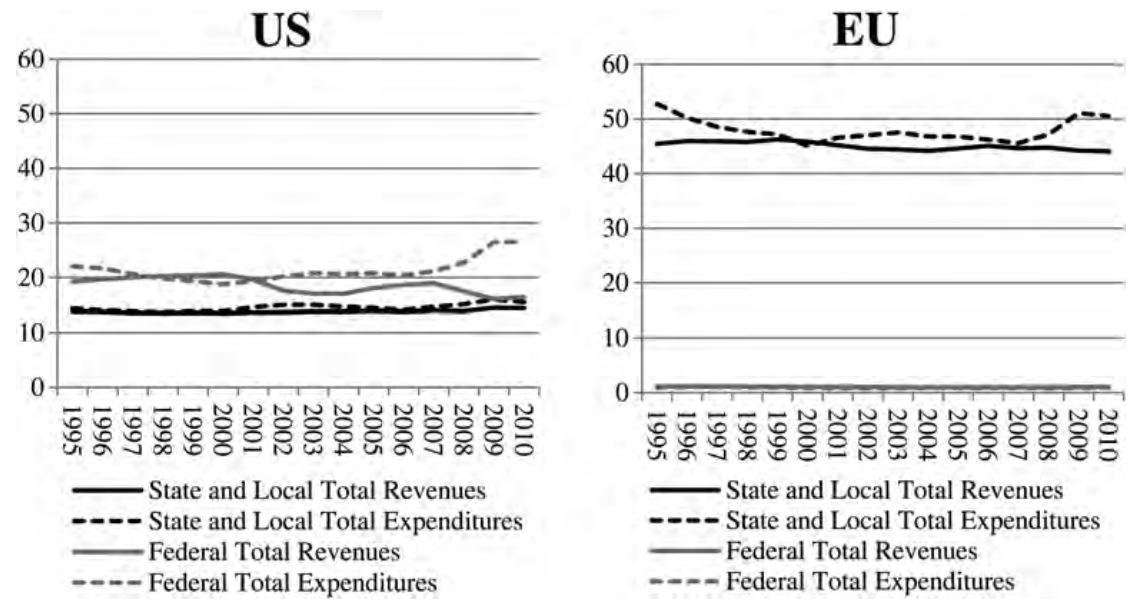

FIGURE 3. US and EU total receipts and expenditure by level of government in percentage of GNI (source: BEA and EUROSTAT).

substantial public finance surplus accompanied by a current account surplus. The same (with opposite sign) is shown for the poorest region (Calabria).

\section{THE TINY EU FEDERAL BUDGET}

If we look at the $27 \mathrm{EU}$ countries as a single federated state, it would appear as almost completely deprived of a system of federal revenue and expenditures. The budget of the European Union is really a small thing when compared with the federal budget of the USA, a set of states comparable in size and importance to the European states.

Over the last fifteen years, in the USA the average weight of federal total receipts has been $18.6 \%$ of Gross National Income (GNI), while federal total expenditure has weighted $21.3 \%$ of GNI. During the same period, total federal receipts and expenditure in the EU both averaged around 1\% of GNI (Figure 3). This picture is reversed if one looks at the state and the local government levels. In the USA, total state and local revenue and expenditure amounted, respectively, to 13.8 and $14.6 \%$ of GNI; in the EU they were instead equal to respectively $45 \%$ and $48 \%$.

It is not only from the quantitative point of view that the EU budget is negligible when compared with the federal budget of the USA. In the EU there is in fact no federal system of assessment and collection of revenues. Tax revenues are collected by individual states, and are much more transfers from member states than actual tax revenues of the EU. In fact, they are also recorded as receipts and expenses in the budgets of individual countries. The situation is completely different in the USA, where the tax system is primarily a federal system, and many states use the 
assessment of the tax base made at the federal level as a basis for calculating state and local taxes. From this point of view, the relationship between the US federal budget and the US state budget is similar to that which in the EU exists between each member state's central government and its local governments.

It is important to notice that while at the state level in the USA, expenditure and revenue tend to balance (in some states there is either a constitutional or a statutory balanced budget rule to the operating budget), at the federal level —in spite of the longstanding debate about the federal debt ceiling ${ }^{11}$ — deficit spending appears to be widely practiced. In Europe, the federal budget is not only negligible for its entity, but is also always balanced. And the EU states' budgets are strait-laced by ever tightening fiscal rules: even in the last period, when in the USA there is both a substantial increase in expenditure and a decrease in taxation, in Europe the increase in expenditure is much more limited, while there is no decrease in taxation (see Figure 3).

Taxes and expenditures confined to state and local government levels cannot by definition make any redistribution at the federal level. Redistribution at the federal level is therefore almost entirely absent in the EU, while it is relevant in the USA, where, as in every federal union, it does not occur through discretionary actions, but quite automatically by virtue of the fact that many taxes and federal spending programmes vary according to income. Differences in state average income levels cause transfers of financial resources within the federation, without resorting to any kind of intervention on a discretionary basis, and without putting in place a federal fiscal policy differentiated between states.

This redistribution is quite different from that which would be obtained if the system of taxes and transfers operated exclusively between the regions of a single nation. A given level of public transfers generates the same burden for the rich regions whether implemented at the state level or at the federal level, only if the average per capita income in that state is equal to the average per capita income of the whole federation. If the state's per capita income is higher than that of the federation, a change from a state scheme to a federal scheme would imply that the rich regions in the high income country transfer resources not only to the poorer regions of their own state, but in part also to the poorer regions of other states. ${ }^{12}$ In this

11 On the 'debt ceiling impasse', see Jackson (2012).

12 This point can be illustrated by two simple numerical examples. Consider two countries, A and B, each composed of two regions ( $\mathrm{A} 1$ and $\mathrm{A} 2$, and $\mathrm{B} 1$ and $\mathrm{B} 2$ ). In $\mathrm{A} 1$, there are 50 individuals with an income of $\$ 300$ each, in A2 there are 25 individuals with an income of $\$ 150$, in B1 there are 25 individuals with an income of $\$ 300$, and in B2 there are 50 individuals with an income of $\$ 150$. Every individual in $\mathrm{A} 2$ and $\mathrm{B} 2$ must receive a transfer of $\$ 30$. If these transfers were financed by two independent national systems, in A1 each individual would have to pay $\$ 15$, and $\$ 60$ in $\mathrm{B} 1$. If a federal budget is established between $\mathrm{A}$ and $\mathrm{B}$, to achieve the same redistribution in favour of $\mathrm{A} 2$ and $\mathrm{B} 2$, each individual in $\mathrm{A} 1$ and $\mathrm{B} 1$ must pay $\$ 30$. Per capita taxes double in A1 and halve in B1. Country A transfers $\$ 750$ to country B. Alternatively, consider the case that in $\mathrm{A} 1$ and $\mathrm{B} 1$ there are 50 individuals, and 25 individuals in A2 and B2, and per capita income remains the same in every region, except in A1 where it is equal to $\$ 600$. If the same transfers of the first example ( $\$ 30$ each in both A2 and B2) were financed by two independent national systems, individuals in A1 would have to pay $2.5 \%$ of their income, 
way, a scheme of taxes and transfers implemented at the federal level plays both a redistributive function internal to the state, and between states.

The amount of the federal redistribution between different states can only be ascertained by a wide margin of approximation. The problem is that many federal expenditures are not enjoyed by the state in which the expenditure is made. ${ }^{13}$ The same problem arises for taxes. ${ }^{14}$ And we must consider that this redistribution is not a zero-sum game, as it is possible to resort to budget deficits. These highly relevant issues - which also occur in the EU within each state-demonstrate the slipperiness of the ground of the calculation of whether a single territory is receiving back from the central government more or less than what it is contributing in taxes. However, it is undeniable that through a fiscal policy not degenerated to the point of making the fiscal system a regressive one, the richer areas of a united territory give up resources in favour of poorer areas, in the same way in which this takes place between richer and poorer individuals of the same area.

Keeping in mind the complications which we have just mentioned, let us compare the scale of redistribution operated by the US federal budget with that of the EU federal budget.

In the USA, per capita total federal revenue collections and transfers vary significantly in the different states. In Figure 4, all US states (with the exception of the District of Columbia) have been ordered on the horizontal axis by level of per capita GDP, starting from the highest. For each of them, the figure shows the difference between federal total individual income tax and federal total direct payments to individuals, both in per capita terms. Despite the presence of some outliers, it is clear that the richer states of the federation-as one would expect-pay much more in taxes on personal income than the direct transfers to individuals they receive, and vice versa for the poorer states. West Virginia and Mississippi, the two poorest states of the federation in terms of per capita GDP, show a negative balance of US $\$ 3,900$ and US $\$ 3,200$, respectively. Delaware and Alaska, the two richest states, show a positive balance of US $\$ 5,100$ and US $\$ 2,500$, respectively.

Figure 5 gives the same information for the 27 countries of the EU, with the exception of Luxembourg. As in the USA, the balance between taxes and transfers

and individuals in B1 5\%. If a federal budget is established between A and B, both A1 and B1 pay 3.33\% of their income. Country A transfers $\$ 250$ to country B.

${ }^{13}$ In the USA, for example, many elders choose to enjoy in Florida the retirement benefits provided by the federal budget, even if they have spent their working life elsewhere. Virginia and Maryland show a large amount of federal spending in public salaries because of their proximity to Washington, and even the salaries of Washington federal employment allotted to the District of Columbia may not be considered an exclusive expense of that state, since services produced by public employees in the capital benefit the whole federation. Similarly, states in which there are companies that supply weapons to the federal government-Texas being the most prominent example - record a high level of federal spending, even if the service of the defense of the federation can hardly be attributed to a single state.

14 The alcohol- and tobacco-producing states pay a vast amount of taxes, but these taxes ought to be allocated to all states in proportion to the consumption of these products. All companies which for tax purposes register in Delaware generate federal revenues paid by Delaware, even though the value added by these companies is actually generated in other states of the federation. 


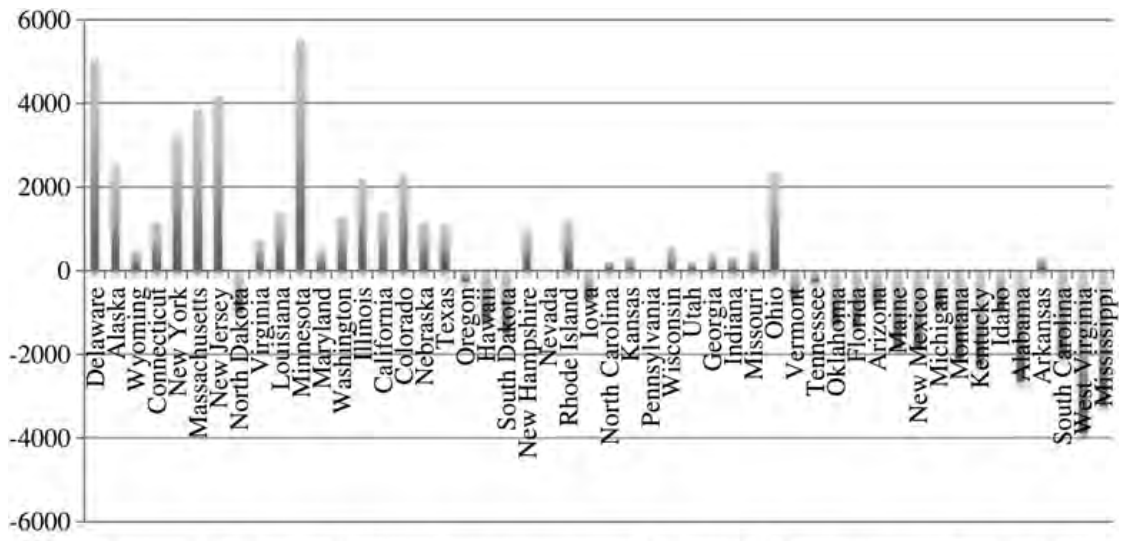

- Per capita Federal total personal income tax minus federal total direct payments to individuals

FiguRE 4. US. Per capita Federal total income taxes minus federal total direct payments to individuals in different states (US\$ per capita). Year 2010 (source: Consolidated Federal Funds Report).

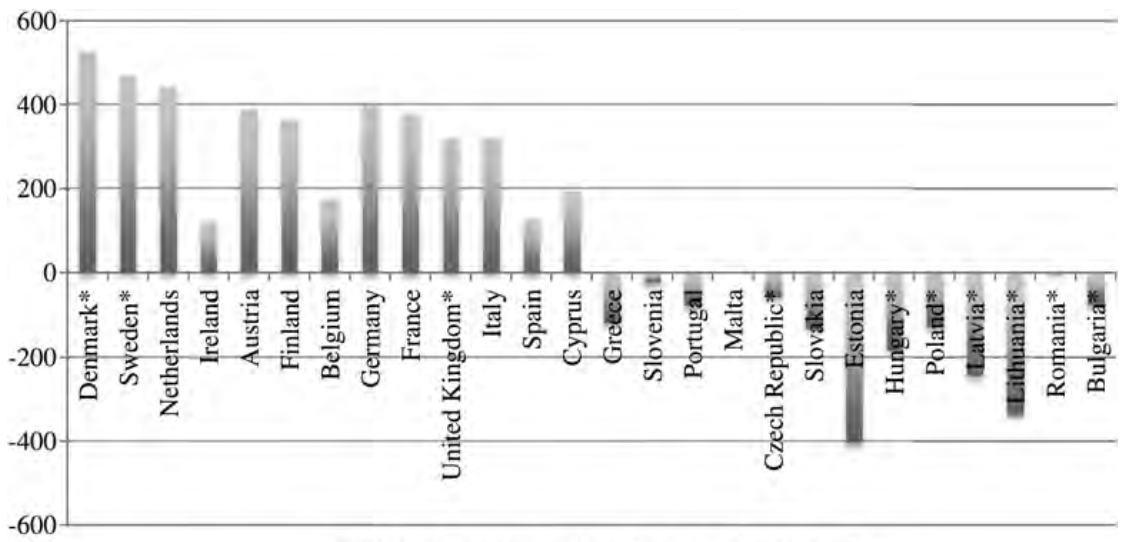

a EU Total revenues minus EU total expenditures

FigURE 5. EU total revenues minus EU total expenditures in different states (€ per capita). Year 2010 (source: EUROSTAT).

tends to decrease with the decrease of per capita GDP. However, in line with what we have seen in Figure 1, we notice that the scale of this redistribution is insignificant when compared with the one made in the USA. Take for example Denmark, the richest country in the union in terms of per capita income; it has the highest difference between federal revenues paid and federal spending received. This amount, however, is little more than $€ 500$ - an amount which would place this state with 
those North American states, such as Wisconsin and Kansas, which show a difference between personal taxes and transfers among the smallest of the federation.

There is still another point to be noticed: the EU budget not only operates minimal redistribution, but this is made across the whole EU27, and in fact its main beneficiaries are countries outside the 17 Euro countries (marked by an asterisk in the figure). The only Euro countries which are net beneficiaries are Greece, Slovakia, Portugal, Slovenia and Estonia. The whole amount of the net contribution they receive is a mere 3 billion Euros.

\section{EXTERNAL IMBALANCES AND THEIR SETTLEMENT}

From the data we have just shown, it appears that the citizens of say Delaware are prepared to 'donate' a not inconsiderable part of their income to say the citizens of Mississippi. The same as in the USA happens within each EU member state, as we have seen in Section 2. Within each EU country-as within the USA-the state makes possible a transfer of real resources from some areas to others through its fiscal policy. This takes place without the necessity of creating debit and credit positions, thus the question of its sustainability does not even arise. As a matter of fact, a creation of debit and credit positions can and will often take place if the state's fiscal policy entails the creation of a budget deficit, and through it the creation of public debt. We may notice, however, that although ownership of public debt will tend to be concentrated in the richer areas, the debt will not be owed by the poorer regions to the richer regions. It will be a debt owed by the nation as a whole, and to this extent it will be an internal debt, and no question of its sustainability can arise so far as its owners are prepared to accept it in 'payment' for the resources they have 'donated' to the poorer regions. Under normal conditions, public debt would be regarded as a first class asset, therefore the most acceptable way of settling these claims.

It is interesting to look in this perspective at the analogous problem when a similar transfer of resources takes place not between different areas of the same state, but between different sovereign states. In the inter-state relationship, such a situation must per se create credit and debit positions, since there is no super entity which could simply 'force' these transfers through its tax power; the situation could be sustainable in the longer term only so far as the creditors agree to see their claims congealed in some acceptable assets. Even when these assets are acceptable, a settlement of the debt must however sooner or later take place in real terms, through the transfer back to the creditor country of the real resources they have temporarily foregone. History, however, shows examples in which the creditor country has accepted to formally relinquish part of its product, agreeing to see its credits indefinitely congealed in a financial asset it cannot control, and which is therefore completely external to it (this appears to be the case of China towards the USA in recent decades). If the creditor is prepared to see its claims indefinitely put on hold, there are no financial aspects which may represent an obstacle. The 
crucial question is therefore to understand the reasons which could make this solution acceptable for the creditor. We think that the basis must be in the economic advantage this would have for the creditor himself. And this advantage can be found in the interest the creditor may have in the growth allowed by effective demand coming from an area outside itself-an external source of demand which is required for that growth to go on without substantially disturbing the distributive conditions of the growing area (China is again a case in point). Of course, the quality of the asset the creditor is receiving is an important element to make the solution acceptable.

The case of an internal imbalance does not in essence differ from the external one. The 'bonds of solidarity' between members of the same nation (common sets of values, religion, language, etc.) are not a cogent explanation of the sustainability of persistent imbalances within a country. Nor does it seem reasonable to attribute it to the mere coercive power of the state: this would imply that the state could act against the interests of the richer-thus more powerful-part of the country. Also within a single state, the mechanism of 'export-led' growth just highlighted may be an important element in the explanation of why persistent imbalances between regions may be acceptable (a significant example may be found in the relationship between Northern and Southern Italy, especially in the early decades after WW2, as well as between East and West Germany after the unification).

From this particular point of view, the exchange of something for nothing which the external imbalance generates can be seen as actually an exchange of something for something: the external demand gives rise to an additional product which would have not otherwise been called into existence. The portion which is given to the deficit area is in substance 'paid' by the amount of product the creditor area would have not enjoyed without giving part of the additional product to the outside. In other words, what can make the situation acceptable is the enjoyment by both areas of the growth dividend. This, however, does not do away with the problem of the means of payment which render the deficit area able to purchase its net imports. As we have already noticed, the difference between the intra-state and the inter-state imbalances is to be seen in the different kinds of assets in terms of which the payment takes place. In the former case, this means of payment is an internal asset, which is in the power of the state or its central bank to generate and control: within a state the balance of payments is not a currency problem. In inter-state relatonships, the balance of payments must instead necessarily be a currency problem, because as a rule neither the state nor its central bank has the power to create the asset necessary to settle an imbalance. The member countries of the Euro area find themselves in a condition which is only apparently similar to that of members of a unified currency area: they settle their accounts in terms of a currency which is internal to the area, but (i) this currency cannot be generated by a single member state according to its needs and (ii) the public debt of a debtor country is not regarded as an internal asset by the creditor country. This conflict between having a single currency and keeping 
separate states has in recent years shown itself in the tensions within the system of payments of the Euro area.

\section{AN IMPOSSIBLE TASK FOR A PAYMENT SYSTEM}

The Euro area system of payments is the so-called TARGET system, ${ }^{15}$ which is nothing else than the counterpart of the ISA system of payments within the $\mathrm{USA}^{16}$ - and in fact has been largely inspired by it. It is therefore worthwhile to consider similarities and differences between these two systems, also in view of the fact that the ISA system has never drawn criticisms as sharp and as relevant as those recently raised-especially by German economists — against the TARGET mechanism.

In both systems, central bank settlement creates a credit in the balance sheet of the national central bank of the country to which the payment flows, and a debt in the balance sheet of the national central bank of the country from which the payment originates. In both systems, these credits and debits are guaranteed and cleared by the central bank (Fed or ECB). Yet in the ISA system, settlement occurs every year, while in the TARGET system the final settling is on hold indefinitely. This has misled some economists into thinking that the US system is more restrictive than the European one, not allowing persistent imbalances of the current accounts of the different member states. ${ }^{17}$ In fact, it is not.

In the first place, we must notice that imbalances in the system of payments-be it the ISA or the TARGET system-may have nothing to do with current account imbalances. Capital movements can create imbalances not linked to the current account. This is most clearly shown by the case of Italy, which notwithstanding a modest imbalance in her current account, has since July 2011 developed a substantial TARGET liability, essentially driven by capital outflows. We may also notice that ISA imbalances may be generated by pure financial movements which have nothing to do with either current account imbalances or with net financial investments e.g., ISA transactions generated by the fact that not all district central banks act as fiscal agents and depositories for the US Treasury, or by the fact that not all district central banks have the same role in the Fed's open market operations. ${ }^{18}$ Most importantly, even when ISA imbalances reflect imbalances in the current accounts of the different districts, the assets through which the imbalances are settled do not share the same nature as gold certificates or foreign reserves ${ }^{19}$ : final settlement is

${ }^{15}$ For a clear exposition of the main characteristics of the TARGET system, see Whelan (2012). See also Cecioni \& Ferrero (2012).

16 For a clear exposition of the ISA system, see Koning (2012).

17 Cfr. Sinn \& Wollmershäuser (2012, p. 496 ff).

${ }^{18}$ In other words, the same transactions would result in a completely different picture of ISA imbalances if the Fed ran open market operations through a different district bank than the NY Fed, or used as fiscal agent and depositories a district bank rather than another.

19 The ISA system was established in 1935, replacing the Gold Settlement Account system (GSA). In the GSA, interdistrict balances had ultimately to be paid on a daily basis in gold certificates. Each district bank had to meet the minimum threshold of $\$ 1$ million in gold certificates. The end of the GSA 
achieved through shifts in holdings of the System Open Market Account (SOMA), which is the pool of dollar-denominated assets acquired via open market operations by district central banks on behalf of the Fed, and allocated among each of them according to their needs. Put more explicitly, the settlement operated by the Fed consists in a transfer of central bank money itself, not of assets (such as gold certificates or foreign reserves) it cannot create.

The SOMA portfolio consists largely of US treasury securities. ${ }^{20}$ Normally, therefore, the regulation between different federal districts takes place by 'shifting' public debt securities held in the Fed SOMA portfolio from a district central bank to another. If a similar settlement were to be made in the TARGET system, it would be made by transferring say Greek public debt to the Bundesbank. It is difficult to think that a settlement of this kind could be more acceptable than the present one to the creditor country, given that its TARGET credit is just the result of its failure to export capital to the debtor countries. Under the present system, the creditor countries are 'paid' by recording a credit in their TARGET accounts. Also this form of payment seems to be unsatisfactory to them, and in fact it has been suggested that either a cap be put on the accumulation of TARGET debit positions - which would however mean the end of the Euro system ${ }^{21}$-or that TARGET imbalances

coincided with the gold confiscation and the withdrawal from circulation of gold certificates (the Emergency Banking Act of 1933). Since then, treasury bills have acquired increasing importance with respect to gold certificates in the balance sheet of the central bank. A new type of gold certificate was issued only to Federal Reserve banks, and did not appear in circulation (since January 1935 it was not even printed). In the following decades, these 'new' gold certificates played a role of declining importance as a regulator of the amount of high powered money. In 1965, the requirement for the maintenance of reserves in gold certificates by Federal Reserve banks against Federal Reserve bank deposit liabilities was abolished; in 1968, the remaining provision under which the Federal Reserve banks were required to maintain reserves in gold certificates against Federal Reserve notes was also abolished. Gold certificates did not play a role in regulating the money supply, that role was restricted to settle credits and debts across federal district banks in the ISA account. In 1975 also this function was abolished. The imbalances between district banks are settled through treasury bills on an annual basis. The gold certificates are today still transferred between district banks, but with the sole purpose of assuring that the amount each bank has in its gold certificate account be equal to the System's average of gold certificates to Federal Reserve notes outstanding. In other words, the gold certificates move following the movement of banknotes between districts, and not the movement of the money supply as a whole.

20 At the end of 2006 , of the $\$ 875$ billion of total assets of the Federal Reserve's consolidated balance sheet, about $\$ 780$ billion were in the domestic SOMA portfolio, which comprised only Treasury securities. On this, see Carpenter et al. (2012).

21 'In a modern, well-functioning economy with a sound financial system, the general public does not draw a distinction between central bank money and commercial bank money, as commercial bank money can easily be converted into central bank money such as banknotes and coins at par. In other words, exchange rates exist between different currencies, while there is a one-to-one "conversion rate" between the two components of a given currency. An essential feature of a national payment system is the fact that it involves the circulation of two types of money which are of uniform value. Preserving the uniform value of the currency is a key task entrusted to the central bank. It is important that a currency have a uniform value, as otherwise a currency cannot perform its "unit of account" function in an effective manner. If banks' liabilities had different values, different prices would have to be set for every good or service for each of the bank monies used, i.e. depending on whether a consumer paid with the liabilities of one bank or another. If the uniform value of the currency was not guaranteed, there would, in effect, be multiple currencies within what is meant to be a single currency area, thereby creating a major obstacle to trade in what is meant to be a single market' (ECB, 2010, p. 45). 
be settled by bonds 'collateralised by each corresponding government with state-owned real estate or senior rights to future tax revenue'. ${ }^{22}$

The means of payment which in the Euro area seem unacceptable to creditor countries are on the other hand perfectly acceptable in the USA. Treasuries are gilt-edged securities. Their price is administered by the central bank. They circulate at par in the whole federal area. The interest rate charged by the central bank is unique in all districts. In Europe, the situation is different. Public debt is issued by different governments. This would not in itself constitute a problem, insofar as the ECB were prepared to guarantee that the treasury bills of all member countries circulate at par in the whole Euro area. In this case, the public debt of European countries, even if issued by different states, would be standardized in the same way as US treasury bills. This would seem to be a necessary outcome of a monetary union: if in a currency area the price of deposits with the banking systems of two different states is the same (i.e. there is uniformity in the value of commercial bank money), it seems natural that there also be a single price for the securities against which central bank money is issued (i.e. there must also be a single interest rate). Yet, in Europe there is no fixing of the price of public debts, since the ECB-in the same way as the Fed with respect to state and local debts-is unwilling to uniform the rate of interest paid on the public debt of different countries, thus giving the market a role in setting the price of different government securities. The treasury bills of some states circulate at a discount. This in itself does not result in immediate failure of the monetary union, and in fact at present in Europe a single currency and interest rate differentials coexist. But whereas a single currency would imply the absence of a balance of payments constraint, the plurality of interest rates shows the unwillingness of the creditor countries to accept a settlement in terms of the public debts-in other words, the presence of a balance of payments constraint.

That unwillingness cannot be explained by mere mercantilist obtusity on the part of the creditor countries; the settlement of a debt in terms of a financial asset, not in real terms, to be acceptable requires either a great strength or a great weakness on the part of the debtor. If the debtor is very powerful, the creditor has a sufficient confidence in his paper. If the debtor is very weak, the creditor has a firm grip on him and his real assets. The debtor countries in the EU fulfil neither of these two conditions: they are weaker than the creditor, but at the same time they are not completely at its mercy-European states are still there. ${ }^{23}$

As we have noticed, European creditor states prefer to be paid in central bank money rather than with paper issued by the debtor states. A settlement in money guaranteed by the central bank is the settlement par excellence for the single individual creditor, but this settlement does not appear as a fully satisfactory solution

22 See Sinn (2012, p.2). For a criticism, see Whelan (2012, p. 41).

23 'It would certainly be no solution to allow the deficit countries to settle their balances with normal government bonds that they issue themselves. That would be akin to jumping from the frying pan into the fire' (Sinn 2012, p. 2). 
for the creditor state as a whole. For the creditor state as a whole, in fact, the only sense in which this settlement may be considered useful is in its allowing an expansion of domestic credit that would have not been otherwise possible. But recording a TARGET credit may not be a necessary condition to enlarge its monetary base. A creditor country may well be in a position such that the monetary policy of the ECB could already be sufficient to meet the needs of its domestic credit. Thus the only effect of the monetary base created through TARGET would be to substitute it for loans to banks from the national central bank. Indeed, this is what has happened in Germany in the last two years, when the Bundesbank's balance sheet saw increments of TARGET credits accompanied by reductions in loans to banks (see Whelan, 2012, fig. 4, p. 15). This does not mean that the TARGET balances crowded out domestic credit, but it is undeniable that the same amount of domestic credit could have been largely assured without that TARGET credit.

For a US federal district, whether reserves are created through credit towards another district or through normal open market operations is equally acceptable. For the creditor countries in the Euro area it is not, and in fact they are showing increasing unwillingness to have their exports paid in the common currency. This is another way of saying that within the Euro area the balance of payments constraint is still present. In the last resort, Euro creditor countries want their exports to Euro countries not to be paid in Euro but in gold and foreign currency reserves. $^{24}$

\section{EXTERNAL CONSTRAINTS AND AUSTERITY RULES IN A COMMON CURRENCY AREA}

One of the main characteristics of a state is that within it there is no balance of payments constraint. We could almost say that what qualifies a state as such is that it brings together a group of areas among which an exchange of something for nothing is acceptable, and the problem of the financial means which render this possible is always solved. The basis of this solution is neither a charitable disposition of the rich areas towards the poor, nor that the poor are able to trick the rich into waiving a portion of their product. It is rather-as we have argued-the growth dividend, which is shared by both.

Fiscal policy is at the root of the working of the growth dividend mechanism, in that it, on the one hand allows the transfer of part of the product from one area to another, and on the other hand (through its expansionary effects) enhances growth.

24 In $2002,82 \%$ of the external position of the Bundesbank was made of gold, special drawing rights, foreign currency reserves and other claims on non-Euro area residents, while $18 \%$ was made of claims within the Euro system and other claims on residents in other Euro area member states. In 2012, they were, respectively, $20 \%$ and $80 \%$ (see Bundesbank 2013, p. 73, table 9). On Germany's export-led growth strategy centred on absorption from the other Euro area countries, see Cesaratto (2011). 
The decades of high growth after WW2 have shown the working of the mechanisms we have tried to highlight, and have had the result of strengthening the territorial cohesion within the states. Even between different states the need to settle the accounts has never got to the point of plunging civilized countries back into worship of the 'barbarous relic', and threatening the very existence of a modern system of payments.

It is by now clear that the establishment of the Euro as a single currency has not worked as a means to overcome the external debt within the area, and its member states, deprived of a central bank, have no other means of managing external imbalances than imposing stern austerity rules. The failure of the EU to tend towards a significant federal fiscal policy has confirmed one of the main points of the neglected MacDougall report on the role of public finance in the European Union: without attributing a major role to the redistributing function of public finance 'monetary union is impracticable' (MacDougall et al., 1977, p. 12). This would have of course required nothing less than the establishment of a single European state.

In the present context, it would be difficult for an individual state to unilaterally implement expansionary policies. A redistributive fiscal policy is hindered by wild forms of tax competition among EU countries. In a highly integrated area, regionspecific expansionary fiscal policies generate strong leakages. These expansionary policies can only be deficit spending policies which would feed current account imbalances. The public debt thus generated would be incurred by a single state initiating the expansion, and would come to be mirrored in an external debt. The country starting the expansion would reap just a small fraction of the expansion, and would also see its external debt growing. As we have seen, the creditor countries would not put on hold the corresponding claims, but would rather use these claims to put pressure on the debtor country. These would be significant obstacles to the action of a single country, the removal of which would require substantial departures from the well-established setting of the 'four fundamental freedoms' on which the current European economic order is based: freedom of movement for capital, people, goods and services.

A common policy would indeed not be met by these obstacles. The fact is, however, that the tendency at the European level is rather the opposite of that recommended by the MacDougall Report, and every reduction of the federal budget is hailed as a victory by member states. No European state appears to be willing to base an expansionary policy on the growth of domestic demand-this would require a significant change in the distributive outlook within these countries. This is particularly evident in the creditor countries, which could to some extent pursue such policies individually, but do not even mildly attempt to do so. This appears to be true also for the debtor countries. The unwillingness of the creditor countries to somehow relax their debtors' external constraint in the last resort allows the debtor countries to pursue restrictive policies which reinforce the present tendencies towards unequal distribution, justifying them as a choice forced upon them from the outside. All European countries are looking for an export-led growth, which would 
indeed be a squaring of the circle. The present policies appear not only to threat the whole European construction, but have started to cause a strong push towards disintegration of the single states, where the richer areas clamour against the poorer areas, showing increasing unwillingness to forego part of their product in their favour. This is most evident in countries like Italy, where of course there is no growth dividend to speak of: not only has her product substantially decreased since the inception of the crisis, but the country has been stagnating for the best part of the last two decades.

\section{REFERENCES}

Bouvet, F. (2010) EMU and the dynamics of regional per capita income inequality in Europe. F. Econ. Inequality, 8, 323-44.

Bundesbank (2013) Monthly Report, January 2013. Frankfurt am Main: Deutsche Bundesbank.

CARPENTER, S., et al. (2012) The Federal Reserve's balance sheet: a primer and projections. Finance and Economics Discussion Series. Washington, DC: Federal Reserve Board.

Cecioni, M. \& Ferrero, G. (2012) Determinants of TARGET2 imbalances, Banca d'Italia Questioni di Economia e Finanza (Occasional papers). http:/www.bancaditalia.it/pubblicazioni/ econo/quest_ecofin_2/qef136/QEF_136.pdf (date last accessed, 28 February 2013).

Cesaratto, S. (2011) Notes on Europe, German mercantilism and the current crisis. The global economic crisis (Brancaccio, E. \& Fontana, G. eds). London: Routledge.

Coughlin, C. C. \& Mandelbaum, T. B. (1988) Why have state per-capita incomes diverged recently? Rev. Federal Reserve Bank St. Louis, 70, 24-36.

ECB (2010) The Payment System (Kokkola, T. ed) Frankfurt am Main: European Central Bank.

EU(2008)Euro@10. Successes and challenges after 10 years of economic and monetary Union. http://ec.europa.eu/economy_finance/publications/publication12682_en.pdf (date last accessed, 28 February 2013).

EUROSTAT (2012) Eurostat regional yearbook 2012. Luxembourg: Publications Office of the European Union.

Gasic, M. \& KuRKowiak, B. (2012) Substantial cross-European differences in GDP per capita, EUROSTAT Statistics in focus, 47/2012.

GiavazZI, F. \& SpaventA, L. (2010) Why the current account may matter in a monetary union. Lessons from the financial crisis in the Euro area. http:/www.igier.unibocconi.it/files/ documents/seminars/Giavazzi_23092010.pdf (date last accessed 28 February 2013).

JACKsON, H. E. (2012) The 2011 debt ceiling impasse revisited, ch.6 of. Is US government debt different? (Allen, F., et al. eds). Philadelphia: University of Pennsylvania Law School \& Wharton Financial Institutions Center.

Koning, J. P. (2012) The idiot's guide to the Federal Reserve Interdistrict Settlement Account. http://jpkoning.blogspot.it/2012/02/idiots-guide-to-federal-reserve.html (date last accessed, 28 February 2013).

MacDougall, D., et al. (1977) Report of the Study Group on the Role of Public Finance in European Integration. Bruxelles: Commission of the European Communities.

MARTIN, R. (2001) EMU versus the regions? Regional convergence and divergence in Euroland. F. Econ. Geography, 1, 51-80.

Shankar, R. \& SHAH, A. (2003) Bridging the economic divide within countries: a scorecard on the performance of regional policies in reducing regional income disparities. World Dev., 31, 1421-1441. 
SINN, H. W. (2012) Fed versus ECB: how TARGET debts can be repaid, Vox column. http://www.voxeu.org/article/fed-versus-ecb-how-target-debts-can-be-repaid (date last accessed, 28 February 2012).

SinN, H. W. \& WollmershäUser, T. (2012) TARGET loans, current account balances and capital flows: the ECB's Rescue Facility. Int. Tax and Public Finance, 468-508.

Whelan, K. (2012) TARGET2 and Central Bank balance sheets, UCD Working Paper Series. http://www.ucd.ie/t4cms/WP12_29.pdf (date last accessed, 28 February 2013).

Wolff, G. B. (2012) A budget for Europe's monetary union, Bruegel Policy Contribution n.22, December. 